\section{Skin Infection with Mycobacterium marinum from a Tropical Fish Tank}

\author{
G. I. BARROW, M. HEWITT
}

British Medical fournal, 1971, 2, 505-506

Opportunist acid-fast bacilli sometimes cause progressive indolent infections of the skin, producing nodules, granulomatous lesions, abscesses, or ulcers. Some of these mycobacteria prefer temperatures lower than $37^{\circ} \mathrm{C}$ for growth, and minor trauma or devitalized tissue probably aid their entry and establishment. One such organism, Mycobacterium marinum (balnei), was identified as the cause of epidemic cutaneous lesions among swimming-pool bathers in Sweden (Linell and Nordén, 1954) and later in Britain (Morgan and Blowers, 1964; Waddington, 1967). It is pathogenic for fish, and sporadic human infection attributed to this source was first reported by Swift and Cohen (1962). We describe a further case of a patient with spreading cutaneous lesions caused by infection with Myco. marinum from a tropical fish tank.

\section{Case History}

A man aged 45 developed a tender papular lesion on the knuckle of the left middle finger in March 1969. Six weeks later several inflamed infiltrated papules and nodules closely resembling blind boils were present on the back of the left fingers, hand, and forearm, with deeper lesions in the upper arm. There were no enlarged lymph nodes, the spleen and liver were not palpable, and routine investigations of the chest, blood, and urine showed nothing abnormal. Histological examination of biopsy material showed a diffuse suppurative inflammation at the dermo-subcutaneous border extending into the adipose tissue, suggesting a pyogenic infection, though no organisms were seen. Despite a course of erythromycin the lesions gradually increased in size and number on the left arm, and sporotrichosis, a mycobacterial or an erysipelothrix infection, and cutaneous leishmaniasis were then considered.

At this stage stained 'smears of granular material extruding from a ruptured nodule revealed scanty pleomorphic acid-fast bacilli among numerous pus cells. Treatment with isoniazid $300 \mathrm{mg}$ daily for six weeks was ineffective. Culture of the 'swabs, however, yielded an acid-fast organism, later identified as Myco. marinum, sensitive in vitro to cycloserine, ethionamide, viomycin, ethambutol, and trimethoprim with sulphamethoxazole. The patient was given two tablets each containing trimethoprim $80 \mathrm{mg}$ and sulphamethoxazole $400 \mathrm{mg}$ twice daily on trial and advised to keep the limb warm. After one week there was noticeable clinical improvement; all active lesions had begun to fade. After five weeks' further treatment with these drugs (one tablet thrice daily for 14 days, one tablet twice daily for 21 days) all the lesions had largely regressed and there wa's no evidence of further activity.

The patient attributed the infection to removal of splinters acquired during gardening. Though the garden contained a pond with goldfish, he also kept a large indoor tropical aquarium in which several fish had recently died. This needed frequent attention, with immersion of his hands in the water. Myco. marinum was isolated from dead fish from the tropical tank, but not from samples of water and swabs of slime and debris from the aquarium and the goldf:sh pond.

Bacteriology.-All specimen's, including swabs taken from the dead fish after homogenization and from centrifuge deposits of the

Public Health Laboratory, Royal Cornwall Hospital (City), Truro, Cornwall

G. I. BARROW, M.D., M.R.C.PATH., DIP.BACT., Consultant Bacteriologist and Director

West Cornwall Clinical Area

M. HEWITT, M.B., F.R.C.P., Consultant Dermatologist aquarium and garden-pond water, were treated with $5 \%$ oxalic acid for 15 minutes followed by $5 \%$ sodium citrate (Nassau, 1954). Löwenstein-Jensen slopes (Oxoid) with and without glycerol were then inoculated and incubated in pairs at $37^{\circ} \mathrm{C}, 33^{\circ} \mathrm{C}$, and room temperature. All slopes inoculated with material from the patient's lesion and the dead fish yielded a pleomorphic acid-fast organism, growth of which was first visible within two weeks and which was subsequently best at $33^{\circ} \mathrm{C}$ but poor at $37^{\circ} \mathrm{C}$. Both strains had the cultural characters and lipid structure of $M y c o$. marinum (Szulga, et al., 1966). Sensitivity tests on solid media incorporating antibiotics at different concentrations were performed at the Tuberculosis Reference Laboratory, Cardiff, and interpreted as described by Leat and Marks (1970) in parallel with normal Myco. tuberculosis, except that Myco. marinum was incubated at $25^{\circ} \mathrm{C}$. A disc diffusion method was used for trimethoprim with sulphamethoxazole. Compared with Myco. tuberculosis, both strains of Myco. marinum were resistant to streptomycin (10 $\mu \mathrm{g} / \mathrm{ml})$, para-aminosalicylic acid $(0.45 \mu \mathrm{g} / \mathrm{ml})$, isoniazid $(0.07$ $\mu \mathrm{g} / \mathrm{ml})$, rifampicin $(20 \mu \mathrm{g} / \mathrm{ml})$, thiacetazone $(1.25 \mu \mathrm{g} / \mathrm{ml})$, and capreomycin $(45 \mu \mathrm{g} / \mathrm{ml})$, but were sensitive to cycloserine (20 $\mu \mathrm{g} / \mathrm{ml})$, ethionamide $(20 \mu \mathrm{g} / \mathrm{ml})$, viomycin $(60 \mu \mathrm{g} / \mathrm{ml})$, ethambutol $(2.6 \mu \mathrm{g} / \mathrm{ml})$, and trimethoprim with sulphamethoxazole.

\section{Comment}

This case illustrates an unusual source of the infection (British Medical fournal, 1970). Though a recognized hazard among bathers, particularly in swimming pools but occasionally in lakes and rivers, there are few reports of infection derived from fish, and only one from Britain (Pegum, 1967). Similar cases of infection from tropical fish tanks were reported by Miller (1969) and by Adams et al. (1970). In another recent case (Mansson et al., 1970) the organism was probably introduced into the patient's tropical aquarium by water-fleas obtained from ponds. In addition to these sources, Dickey (1968) described the case of a patient infected with Myco. marinum probably derived from water from an old well. Most of these patients gave a history of preceding minor trauma, and removal of garden splinters in the present case may well have allowed initial entry of the mycobacterium from the fish tank.

Myco. marinum was first isolated by Aronson (1926) from fish dying in a marine aquarium. It grows best at $30-33^{\circ} \mathrm{C}$, and very poorly or not at all at $37^{\circ} \mathrm{C}$. Isolation is therefore unlikely unless cultures are incubated at suitable temperatures. For pretreatment of specimens a mild method such as that of Nassau (1954) is preferable. The mycobacterial nature of the infection may also be established by histological examination, though this has usually proved unrewarding with Myco. marinum, partly due to the limited material available and partly because histological findings vary with the age of the lesion. In some instances, as with the present patient, the main finding was a diffuse subacute inflammatory reaction with scattered microabscesses, but without the histological features of a tuberculoid reaction. In other patients, usually with long-standing lesions, epithelioid foci, giant cells, or tuberculoid granulomata were-observed, though acid-fast bacilli were rarely demonstrable (Linell and Nordén, 1954; Schaefer and Davis, 1961). The diagnosis of infection with this organism thus presents many difficulties, and it should be considered in all patients with obscure localized inflammatory lesions of the skin, especially if limited to one hand or arm.

Infections caused by $M y c o$. marinum vary in their response to treatment with antituberculosis drugs. In our case the organism was sensitive in vitro to, among other drugs, trimethoprim with sulphamethoxazole, which were tried clinically with surprising effect. Though advice to keep the limb as warm as possible might have helped, the prompt and unexpected response to these drugs contrasts sharply with the usual slow course of spontaneous resolution. It is therefore important that the efficacy of trimethoprim with sulphamethoxazole in further cases of Myco. marinum infection should be investigated. 
We are grateful to Dr. J. Marks, Tuberculosis Reference Laboratory, Cardiff, for identification of the organisms and for sensitivity tests, to Dr. R. Salm for the histological reports, and to Miss Angela Toy for technical assistance

\section{References}

Adams, R. M., Remington, J. S., Steinberg, J., and Seibert, J. S. (1970). fournal of the American Medical Association, $211,457$. Aronson, J. D. (1926). Fournal of Infectious Diseases, 39, 315. British Medical fournal, 1970, 2, 438.
Linell, F., and Nordén, A. (1954). Acta Tuberculosea Scandinavica, Suppl. No. 33, p. 1.

Mánsson, T., Brehmer-Andersson, E., Wittbeck, B., and Grubb, R. (1970). Acta Dermato-venereologica, 50, 119.

Morgan, J. K., and Blowers, R. (1964). Lancet, 1, 1034.

Miller, R. (1969) Archives of Dermatology, $100,780$.

Miller, R. (1954). Archives of Dermatology, 100, 780.

Pegum, J. S. (1967). Transactions of the St. Fohn's Hospital Dermatological Society, 53, 119 .

Schaefer, W., and Davis, C. (1961). American Review of Respiratory Diseases, 84, 837 .

Swift, S., and Cohen, H. (1962). New England fournal of Medicine, 267, 1244

Szulga, T., Jenkins, P. A., and Marks, J. (1966). Tubercle, 47, 130.

Waddington, E. (1967). Transactions of the St. Fohn's Hospital Dermatological Society, 53, 122.

\section{Sicca Syndrome Due to Primary Amyloidosis}

\section{A. KUCZYNSKI, R. J. COURTENAY EVANS, M. J. MITCHINSON}

\section{British Medical fournal, 1971, 2, 506}

Amyloidosis, especially primary amyloidosis, is well known as a mimic of other diseases. Though it has often been described in the cornea, conjunctiva, and eyelid (Brownstein, 1968) and rarely in other parts of the eye and orbit it has not apparently been reported to affect the lacrimal gland. The following report suggests that amyloidosis should be considered in the differential diagnosis of the sicca syndrome.

\section{Case Report}

A 71-year-old gardener presented in April 1970 with a short history of breathlessness and swollen ankles. On examination he was noted to have a raised jugular venous pressure, basal crepitations, hepatomegaly, and peripheral oedema. The pulse was regular, blood pressure was $180 / 90 \mathrm{~mm} \mathrm{Hg}$, and heart sounds were normal. There was an ejection systolic murmur but no cardiac enlargement. In addition, it was noted that the mouth was very dry and lacking in saliva. On direct questioning he admitted having had a dry mouth and "gritty eyes" for about one year.

Schirmer's test for lacrimation was positive. A chest $x$-ray picture was normal; there was no evidence of cardiac enlargement. Electrocardiograms showed left ventricular preponderance but no other abnormality. In addition, he was found to be in moderate renal failure, with a blood urea of $138 \mathrm{mg} / 100 \mathrm{ml}$ and a serum creatinine of $2.8 \mathrm{mg}$ / $100 \mathrm{ml}$. An intravenous pyelogram showed diminished excretion but no other obvious abnormality. Serum electrolytes, urine microscopy and culture, and serum calcium and phosphorus were all normal. Liver function tests showed a serum alkaline phosphatase of 54 King-Armstrong units and a slightly raised serum alanine aminotransferase of 68 units. Serum bilirubin was $0.9 \mathrm{mg} / 100 \mathrm{ml}$. The erythrocyte sedimentation rate (Westergren) was $38 \mathrm{~mm}$ in the first hour, haemoglobin $13.8 \mathrm{~g} / 100 \mathrm{ml}$, and white cell count $9,200 /$ $\mathrm{mm}^{3}$ with a normal differential.

These investigations showed that he had renal, hepatic, and cardiac disease in addition to the "sicca syndrome." A tentative diagnosis of a connective-tissue disease was made but lupus erythematosus cells and antinuclear factor were not found and the plasma protein electrophoresis was normal. A liver biopsy specimen was reported to show only mild non-specific abnormalities. A technetium liver scan showed multiple filling defects suggesting secondary neoplastic deposits; barium studies of the gastrointestinal tract showed no primary site. No definite diagnosis was established and he was treated symptomatically with diuretics and discharged from hospital.

\section{Addenbrooke's Hospital, Cambridge CB2 2AH}

A. KUCZYNSKI, M.B., B.S., Wellcome Research Fellow

R. J. COURTENAY EVANS, M.B., M.R.C.P., Senior Registrar

Cambridge University, Cambridge CB2 1QP

M. J. MITCHINSON, M.D., M.R.C.PATH., Lecturer in Pathology
In June 1970 he was noted to have developed bilateral foot-drop; soon after this he went into liver failure, which presented with an obstructive jaundice. Again he was treated symptomatically with neomycin, dietary restriction of protein, and diuretics. The liver at this time appeared to be increasing in size. After recurrent bouts of liver failure he died from a combination of oliguric renal failure and hepatic failure five months after first presenting.

Necropsy. - The body was wasted, jaundiced, and covered with petechiae. Serous effusions were present in the pleural and peritoneal cavities. A pscudocyst of the pancreas was present. The main abnormal finding was gross amyloidosis of liver, spleen, kidneys, and heart. Histological examination confirmed the presence of amyloid in these organs and also in the testes, tongue, pituitary, lymph nodes, ocsophagus, pancreas, adrenals, and thyroid. Sections from the left parotid and lacrimal glands showed deposition of amyloid in intcrlobular septa and between acini which, especially in the parotid, were somewhat atrophic. Apart from a few scattered lymphocytes in the section of the parotid, the lacrimal and salivary glands showed no cellular infiltrate or fibrosis. The histological picture appeared to exclude the possibility of active or healed inflammation. Amyloid was also present in the walls of small arteries and sebaceous glands in the eyelid. Amyloid stains on sections of the previous liver biopsy specimen showed that amyloid was present, but in such small amounts as to be imperceptible without special stains. The cause of death was recorded as renal, hepatic, and cardiac failure due to "primary" amyloidosis.

\section{Comment}

The lack of inflammation or fibrosis in lacrimal and salivary glands excludes the common chronic inflammatory form of the sicca syndrome. There seems little doubt in retrospect that in this patient the clinical syndrome was due to amyloidosis. The lack of chronic inflammation here or elsewhere in the body and the distribution of amyloidosis suggests the "primary" form.

This case illustrates once again the varied clinical guises of amyloidosis and raises a further possible diagnosis to bc considered in sicca syndrome. Clearly the entity described here is rare, but might occasionally require to be distinguished from Sjögren's syndrome with secondary amyloidosis, which has been recognized previously (Gardner, 1965).

An association of sicca syndrome with hepatic and renal failure, as seen in the present case, will also require to be distinguished from the combination of sicca syndrome with autoimmune liver disease (Golding et al., 1970) and with hyperglobulineamic renal tubular acidosis (Mason and Golding, 1970).

We are grateful to Professor Ivor Mills and Dr. G. Austin Gresham for permission to report this account.

\section{References}

Brownstein, M. H. (1968). Medical Times, 96, 232

Gardner, D. L. (1965). Pathology of the Connective Tissue Diseases, p. 86, London, Arnold.

Golding, P. L., Bown, R., Mason, A. M. S., and Taylor, E. (1970). British Medical fournal, 4, 340.

Mason, A. M. S., and Golding, P. L. (1970). British Medical fournal, 3, 143. 